\title{
Brucella arthritis: a study of 96 cases in Kuwait
}

\author{
Monther I Khateeb, George F Araj, Said A Majeed, AbdulRaouf R Lulu
}

\begin{abstract}
Of 400 patients with brucellosis, 104 (26\%) had arthritis, of whom 96 could be followed up. The systemic disease in the 96 patients was acute in $54(56 \%)$, subacute in $24(25 \%)$, and chronic in $18(19 \%)$. The main presenting symptoms were joint pain, fever, sweating, and easy fatigability. The joints most commonly affected were the sacroiliac joint (26\%) and knee (25\%) followed by hip (18\%) and spine (8\%). There was no particular pattern of joint affection in relation to age. Joint effusion occurred in 32/104 (30\%) of cases, predominantly $(94 \%)$ in the acute group. Culture of synovial fluid was negative in all, and analysis of synovial fluid for cellular profile, glucose, and protein content was not particularly helpful in diagnosis. Plain radiographs did not show major pathological changes. Among the laboratory tests, including haematological and liver function tests, the brucella encyme linked immunosorbent assay (ELISA) was the most reliable in the diagnosis of disease, using serum and synovial fluid specimens. Treatment with a combination of streptomycin plus tetracyclines or rifampicin resulted in an excellent cure rate and resolution of arthritis without sequelae or mortality. Thus brucellosis should be considered in the differential diagnosis of arthritis, especially in areas in which the disease is endemic.
\end{abstract}

Over 100 years after its recognition brucellosis still imposes a considerable public health, veterinary, and economic toll in several countries around the world. ${ }^{1-4}$ The Brucella spp which cause human infection include $B$ melitensis, $B$ abortus, $B$ suis, and $B$ canis. Infection is transmitted to man mainly by ingestion of unpasteurised milk or its products or by contact with infected animals, and by inhalation or through abraded skin and conjunctiva. Although brucellosis is now found in only a few cases in the industrialised countries, it is still endemic in developing countries, especially in Latin America, the Mediterranean, and Middle Eastern countries. ${ }^{6-8}$ In Kuwait and neighbouring countries the disease has reached an almost epidemic proportion-70 cases $/ 100000$ population. 9

Clinically, brucellosis usually presents as fever of unknown origin, but the disease may have polymorphic features affecting various body organs. 589 The osteoarticular system is one of the most commonly affected, with arthritis being the main feature. ${ }^{10}$

Previously, we reported a prospective study of $\mathbf{4 0 0}$ patients with brucellosis. ${ }^{9}$ In this report we describe our experience with 96 patients with arthritis due to brucellosis.

\section{Patients and methods}

In a prospective study of 400 cases with brucellosis 104 cases (26\%) had articular disease. The detailed criteria for diagnosis as well as the clinical and laboratory findings for these $\mathbf{4 0 0}$ patients have been presented elsewhere. ${ }^{911}$ Based on the systemic disease duration before admission to hospital, patients were classified as acute brucellosis ( $<2$ months), subacute brucellosis (2-12 months), and chronic brucellosis (>12 months).

Arthritis was diagnosed by the presence of pain or tenderness, or both, restriction of movement, and swelling. Swelling was not essential for the diagnosis of hip, spine, or sacroiliac arthritis, however. Additional signs such as effusion, warmth, and redness, though encountered in many cases, were not considered essential for the diagnosis of arthritis. Joint fluid, when aspirated, was cultured, Gram stained, and tested for antibrucella antibodies by the microagglutination test and by enzyme linked immunosorbent assay (ELISA), for cell count and differential, and for protein and glucose concentrations. Arthritis occurred for the first time in all patients within the week before admission to hospital.

Other investigations included haemoglobin and leucocyte count and differential, erythrocyte sedimentation rate, biochemical profiles for liver and renal function tests, rheumatoid factor, LE cells, antistreptolysin $O$ titre, $C$ reactive protein, malaria film, Widal's test, and tests for rubella, coxsackie, and Epstein-Barr viruses. Radiological examination was performed for all affected joints.

Testing for and absorption of rheumatoid factor was carried out on sera using ArthriSlidex kit reagents (Bio Merieux, France).

\section{TREATMENT}

Combined antibrucella treatment with oxytetracycline ( $500 \mathrm{mg}$ four times a day orally for six weeks) plus streptomycin ( $1 \mathrm{~g}$ once a day intramuscularly for 3 weeks) was given to 54 patients, doxycycline ( $200 \mathrm{mg}$ once a day orally for six weeks) plus streptomycin to 15 patients, and rifampicin (900 mg once a day orally for six weeks) plus streptomycin to 27 patients. Nonsteroidal anti-inflammatory drugs (ibuprofen or indomethacin) were used in all patients and corticosteroids were used in two patients. All
Accepted for publication 12 January 1990 
patients were treated as inpatients during the first seven days and were followed up as outpatients thereafter. The efficacy of treatment was assessed by clinical responses and serological tests every two months. Relapse was defined as reappearance of clinical symptoms within six months after completing treatment without a history suggesting a new contact with infected animals or ingestion of unpasteurised milk or its products, as well as report of relapse by microbiological and serological methods. All relapses were considered as indications for a different course of drug treatment than that used at the initial attack.

\section{Results}

\section{DEMOGRAPHIC INFORMATION}

The results for $96 / 104$ (92\%) patients with brucellar arthritis are presented; eight patients were lost to follow up.

Brucellosis was acute in $54(56 \%)$, subacute in $24(25 \%)$, and chronic in $18(19 \%)$ of the cases. The overall male to female ratio was $2: 1$. Patient's ages ranged from 13 to 75 years, with 74 being $<40$ years of age.

Table 1 Presenting symptoms and signs in 96 patients with brucella arthritis

\begin{tabular}{|c|c|c|c|c|}
\hline \multirow{2}{*}{$\begin{array}{l}\text { Symproms } \\
\text { and signs }\end{array}$} & \multicolumn{3}{|c|}{$\%$ Of patients in category: } & \multirow{2}{*}{$\underset{(n=96)}{\text { Total No }}(\%)$} \\
\hline & $\begin{array}{l}\text { Acute } \\
(n=54)\end{array}$ & $\begin{array}{l}\text { Subacute } \\
(n=24)\end{array}$ & $\begin{array}{l}\text { Chronic } \\
(n=18)\end{array}$ & \\
\hline $\begin{array}{l}\text { Symptoms } \\
\text { Arthralgia } \\
\text { Fever } \\
\text { Sweating } \\
\text { Fatigue/weakness } \\
\text { Chills } \\
\text { Low back pain } \\
\text { Myalgia } \\
\text { Anorexia } \\
\text { Headache } \\
\text { Vomiting } \\
\text { Loss of weight } \\
\text { Constipation } \\
\text { Cough } \\
\text { Insomnia } \\
\text { Abdominal pain } \\
\text { Depression } \\
\text { Diarrhoea } \\
\text { Scrotal pain }\end{array}$ & $\begin{array}{r}100 \\
98 \\
89 \\
85 \\
72 \\
67 \\
45 \\
45 \\
26 \\
20 \\
20 \\
13 \\
4 \\
6 \\
6 \\
0 \\
4 \\
4\end{array}$ & $\begin{array}{r}100 \\
91 \\
95 \\
91 \\
91 \\
75 \\
62 \\
50 \\
21 \\
25 \\
25 \\
17 \\
21 \\
13 \\
17 \\
8 \\
8 \\
4\end{array}$ & $\begin{array}{r}100 \\
77 \\
72 \\
72 \\
50 \\
66 \\
33 \\
44 \\
44 \\
22 \\
6 \\
17 \\
17 \\
17 \\
6 \\
17 \\
0 \\
0\end{array}$ & $\begin{array}{ll}96 & (100) \\
89 & (93) \\
84 & (88) \\
81 & (84) \\
70 & (73) \\
66 & (69) \\
46 & (48) \\
44 & (46) \\
27 & (28) \\
21 & (22) \\
18 & (19) \\
14 & (15) \\
10 & (11) \\
9 & (9) \\
8 & (8) \\
5 & (5) \\
4 & (4) \\
3 & (3)\end{array}$ \\
\hline $\begin{array}{l}\text { Signs } \\
\text { Arthritis } \\
\text { Hepatosplenomegaly } \\
\text { Splenomegaly alone } \\
\text { Hepatomegaly alone } \\
\text { Orchitis }\end{array}$ & $\begin{array}{r}100 \\
41 \\
91 \\
5 \\
4\end{array}$ & $\begin{array}{r}100 \\
50 \\
33 \\
4 \\
4\end{array}$ & $\begin{array}{r}100 \\
44 \\
11 \\
11 \\
0\end{array}$ & $\begin{array}{rr}96 & (100) \\
42 & (44) \\
20 & (21) \\
6 & (6) \\
3 & (3)\end{array}$ \\
\hline
\end{tabular}

Table 2 Haematological findings in 96 patients with brucella arthritis

\begin{tabular}{|c|c|c|c|c|}
\hline \multirow[t]{2}{*}{ Test } & \multicolumn{3}{|c|}{$\%$ Of patients in category: } & \multirow{2}{*}{$\begin{array}{l}\text { Total No (\%) } \\
(n=96)\end{array}$} \\
\hline & $\begin{array}{l}\text { Acute } \\
(n=54)\end{array}$ & $\begin{array}{l}\text { Subacute } \\
(n=24)\end{array}$ & $\begin{array}{l}\text { Chronic } \\
(n=18)\end{array}$ & \\
\hline \multicolumn{5}{|c|}{$\begin{array}{l}\text { White blood cell count } \\
\left(\times 10^{9} \pi\right)\end{array}$} \\
\hline $\begin{array}{l}<4 \\
>10\end{array}$ & $\begin{array}{l}11 \\
19\end{array}$ & $\begin{array}{l}13 \\
25\end{array}$ & 11 & $\begin{array}{l}11(11) \\
18(19)\end{array}$ \\
\hline \multirow{4}{*}{$\begin{array}{l}\text { Lymphocytes (\%) } \\
\geq 45 \\
\text { Polymorphs (\%) } \\
\geqslant 75 \\
\text { Platelets }\left(\times 10^{9} /\right) \\
<100\end{array}$} & 43 & 42 & 28 & $38(40)$ \\
\hline & & & & \\
\hline & 9 & 17 & 28 & $14(15)$ \\
\hline & \multicolumn{4}{|c|}{$\begin{array}{c}100-400 \\
\operatorname{ESR}^{*}(\mathrm{~mm} / \mathrm{h})\end{array}$} \\
\hline \multirow{2}{*}{$\begin{array}{l}20-50 \\
>50 \\
\text { Haemoglobin }(\mathrm{g} / \mathrm{l}) \\
\leqslant 100\end{array}$} & $\begin{array}{l}41 \\
40\end{array}$ & $\begin{array}{l}50 \\
29\end{array}$ & $\begin{array}{l}33 \\
50\end{array}$ & $\begin{array}{l}40(42) \\
37(39)\end{array}$ \\
\hline & 11 & 20 & 6 & $12(13)$ \\
\hline
\end{tabular}

ESR=erythrocyte sedimentation rate.
The disease was mostly due to ingestion of unpasteurised milk and was occupational in only 22 patients.

\section{CLINICAL FEATURES}

Table 1 lists the main symptoms and signs noted on presentation. Joint pain, fever, sweating, and easy fatigability were the main presenting symptoms regardless of the disease category. Patients with acute brucellosis were more toxic and sick than the others, however. Headache, depression, and insomnia were mostly seen in the chronic group.

\section{HAEMATOLOGICAL FINDINGS}

Table 2 presents the haematological findings, which were normal in most patients. Relative lymphocytosis and raised erythrocyte sedimentation rate were noted in $40 \%$ and $81 \%$ of patients respectively. There were no cases of pancytopenia or disseminated intravascular coagulopathy.

\section{LIVER FUNCTION TESTS}

Among the different liver function tests, abnormal findings were found in up to $32 \%$ of the patients, being higher in the subacute than in the acute or chronic groups.

\section{BRUCELLA BLOOD CULTURE AND SEROLOGICAL}

FINDINGS

Blood culture and agglutination tests were less positive than ELISAs (table 3). The ELISA IgG, IgM, and IgA were consistently raised in almost all patients ( $\geqslant 98 \%$ ) with acute and subacute brucellosis. In patients with chronic brucellosis, however, IgG and IgA were raised in all but IgM was only raised in 33\% (6/18).

C REACTIVE PROTEIN, RHEUMATOID FACTOR, AND ANTISTREPTOLYSIN O TITRE

$\mathrm{C}$ reactive protein was positive in around 53 $(55 \%)$ of all patients. The rheumatoid factor was positive in only four patients (three acute and one subacute). The rheumatoid factor absorbed serum samples showed no significant changes in antibrucella IgG, IgM, or IgA antibody concentrations compared with the homologous nonabsorbed sera. Antistreptolysin $\mathrm{O}$ titres in all patients were $\leqslant 200$ Todd units.

\section{ARTICULAR COMPLICATIONS}

Arthritis occurred for the first time in all patients within one week before admission to hospital. It was one of the main presenting clinical features (table 1). Joint effusion occurred in 32 of 104 patients (30\%)-predominantly $(94 \%)$ in acute, few (6\%) in subacute, and none in the chronic groups. The effusion was elicited in knee, ankle, and wrist joints in descending order.

The joint most commonly affected was the sacroiliac joint (26\%), predominantly unilaterally, and the incidence was similar in the three 
Table 3 Blood culture and serological findings in 96 patients with brucella arthritis

\begin{tabular}{|c|c|c|c|c|}
\hline \multirow{2}{*}{$\begin{array}{l}\text { Brucella } \\
\text { test }^{*}\end{array}$} & \multicolumn{3}{|c|}{$\%$ Of positive findings in category: } & \multirow{2}{*}{$\begin{array}{l}\text { Total No (\%) } \\
(n=96)\end{array}$} \\
\hline & $\begin{array}{l}\text { Acute } \\
(n=54)\end{array}$ & $\begin{array}{l}\text { Subacute } \\
(n=24)\end{array}$ & $\begin{array}{l}\text { Chronic } \\
(n=18)\end{array}$ & \\
\hline $\begin{array}{l}\text { Culture } \\
\text { Slide agglutination } \\
\text { Microagglutinaton } \\
\text { ELISA }\end{array}$ & $\begin{array}{l}28 \\
93 \\
94\end{array}$ & $\begin{array}{l}25 \\
88 \\
92\end{array}$ & $\begin{array}{r}0 \\
67 \\
72\end{array}$ & $\begin{array}{l}21(22) \\
83(86) \\
86(90)\end{array}$ \\
\hline $\begin{array}{l}\text { CLIS } \\
\operatorname{Ig} \\
\lg \\
\text { IgA }\end{array}$ & $\begin{array}{r}98 \\
100 \\
98\end{array}$ & $\begin{array}{l}100 \\
100 \\
100\end{array}$ & $\begin{array}{r}100 \\
33 \\
100\end{array}$ & $\begin{array}{l}95(99) \\
90(94) \\
95(99)\end{array}$ \\
\hline
\end{tabular}

"Titres for microagglutination ( $\geqslant 1 / 80)$; for ELISA IgG $(\geqslant 1 / 1600)$, IgM $(\geqslant 1 / 400)$, and IgA $(\geqslant 1 / 200)$. These were considered the cutoff titres for raised (positive) findings as they showed high discrimination $(\geqslant 98 \%)$ in sensitivity and specificity compared with controls. 1

Table 4 Affected joints in 96 patients with brucella arthritis

\begin{tabular}{|c|c|c|c|c|}
\hline \multirow[t]{2}{*}{ foint } & \multicolumn{3}{|c|}{$\%$ Of patients in category: } & \multirow{2}{*}{$\begin{array}{l}\text { Total No }(\% \\
(n=96)\end{array}$} \\
\hline & $\begin{array}{l}\text { Acute } \\
(n=54)\end{array}$ & $\begin{array}{l}\text { Subacure } \\
(n=24)\end{array}$ & $\begin{array}{l}\text { Chronic } \\
(n=18)\end{array}$ & \\
\hline $\begin{array}{l}\text { Sacroiliac: } \\
\text { Unilateral } \\
\text { Bilateral } \\
\text { Knee } \\
\text { Hip } \\
\text { Spondylitis } \\
\text { Ankle } \\
\text { Polyarthritis } \\
\text { Shoulder } \\
\text { Wrist } \\
\text { Elbow } \\
\text { Others* }\end{array}$ & $\begin{array}{r}24 \\
0 \\
24 \\
20 \\
11 \\
9 \\
7 \\
0 \\
2 \\
0 \\
2\end{array}$ & $\begin{array}{r}25 \\
8 \\
17 \\
17 \\
4 \\
0 \\
8 \\
13 \\
13 \\
0 \\
4 \\
4\end{array}$ & $\begin{array}{r}22 \\
0 \\
39 \\
11 \\
6 \\
11 \\
0 \\
6 \\
6 \\
0 \\
0\end{array}$ & $\begin{array}{r}23(24) \\
2 \quad(2) \\
24(25) \\
17(18) \\
8(8) \\
7 \quad(7) \\
6 \quad(6) \\
4 \quad(4) \\
2 \quad(2) \\
1 \quad(1) \\
2 \quad(2)\end{array}$ \\
\hline
\end{tabular}

*Sternoclavicular and temporomandibular.

groups (table 4). The incidence in the knee $(25 \%)$ and the hip (18\%) was slightly less. Other less commonly affected joints included the spine $(8 \%)$, ankle $(7 \%)$, shoulder $(4 \%)$, wrist $(2 \%)$, and elbow (1\%). The figure presents the incidence of joint affection in relation to age; no particular pattern was found. Almost all cases occurred below the age of 50 years.

Plain radiographs showed no major pathological changes.

Distribution of joints affected in brucella arthritis in relation to patients' age.
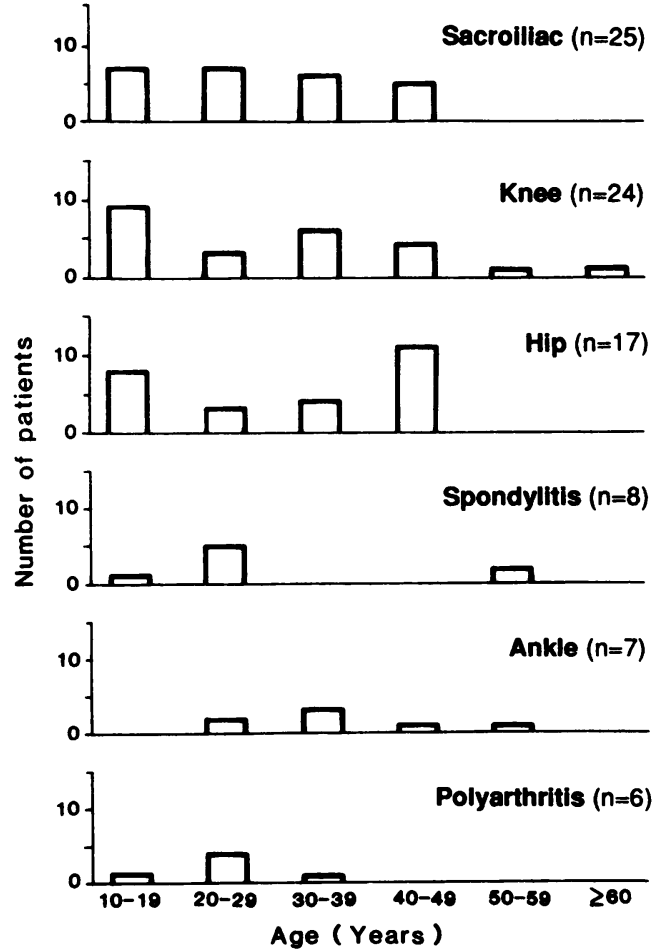

Table 5 Laboratory findings in 13 synovial fluids from patients with brucella arthritis

\begin{tabular}{lll}
\hline Test & \multicolumn{1}{l}{ Findings } \\
\cline { 2 - 3 } & $\begin{array}{l}\text { Range or } \\
\text { Number }\end{array}$ & Mean \\
& & \\
\hline White cell count (cells $\left.\times 10^{9} / 1\right)$ & $0 \cdot 1-15 \cdot 3$ & $3 \cdot 467$ \\
Lymphocytes (\%) & $4-100$ & 37 \\
Polymorphonuclear cells (\%) & $0-96$ & 63 \\
Glucose (mmol/) & $3 \cdot 3-5 \cdot 2$ & $4 \cdot 6$ \\
Protein (g/l) & $43-64$ & 50 \\
Positive brucella culture & $0 / 13$ & \\
Positive brucella serology & $12 / 13$ & \\
MAT* (titre $\geqslant 1 / 80)$ & $13 / 13$ & \\
ELISA (titr $\geqslant 1 / 1600)$ & $4 / 13$ & \\
IgG (titre & $13 / 13$ & \\
IgM (titre $\geqslant 1 / 400)$ & \\
IgA (titre $\geqslant 1 / 200)$ &
\end{tabular}

${ }^{*}$ MAT $=$ microagglutination test.

LABORATORY FINDINGS IN SYNOVIAL FLUID

The synovial fluid from 13 patients with knee effusion was studied and the results are presented in table 5.

Synovial tissue obtained by biopsy from one patient showed diffuse non-specific inflammation with scarce granulomatous fibrous deposits.

FOLLOW UP AND CLINICAL RESULTS

The mean follow up period of all patients was 15 months (range 13-19). Clinical responsesubsidence of fever and arthralgia - was seen in most patients after three to eight days of treatment. Resolution of organomegaly and arthritis was slower(four to six weeks). Generally, arthritis took longer to resolve in patients with spondylitis and sacroiliitis than in others. Treatment failed in five patients owing to true relapse in two and to non-compliance and drug side effects in the others. These patients recovered after a new regimen was used. No sequelae or mortality were registered in our patients.

\section{Discussion}

The $26 \%$ incidence of osteoarticular complications in brucellosis in this study falls within the reported incidence of $11 \%$ to $56 \% .^{710} 12-16$ The wide range of reported incidences might be explained not only by possible geographical variations but also by the lack of agreement on one definition for arthritis. ${ }^{15} 16$

The male to female ratio of $2: 1$ in this series was similar to that of the general study population. ${ }^{9}$ In contrast with others, ${ }^{7} 1617$ our patients did not show any particular pattern of joint affection in relation to age. The predominance of osteoarticular complications in young adults and the lack of association with a particular occupational risk reflect the susceptibility of the general population to brucellosis in an endemic area. 7916

The incidence of affected joints in brucella arthritis also differed among various reports. The sacroiliac joint was the joint most commonly affected in our study. It is difficult to explain the wide variations $(10-56.5 \%)$ in the reported incidence of disease in this joint. ${ }^{7} 1518$ Alarcon et al thought that sacroiliitis was less common than peripheral arthritis, occurring 
mainly in young adults with acute brucellosis. ${ }^{10}$ This was not found in our study as sacroiliitis was most common and occurred in different age groups. Although we carried out bone imaging in only one patient with sacroiliitis, this diagnostic tool has been reported to be valuable as imaging is more sensitive than plain radiography. ${ }^{19} 20$ Our patient with sacroiliitis was in fact erroneously diagnosed clinically as having lumbar disc prolapse, whereas bone imaging showed sacroiliitis with a disease free spine. In this study and in others the sacroiliac, knee, and hip joints were the joints most commonly affected in adults, whereas the knee and hip joints were most commonly affected in children. ${ }^{21}$ The incidence of brucella spondylitis (around 8\%) we found was similar to that found by most studies from various locations, ${ }^{7} 101622$ but Lifeso et al reported a higher incidence (30\%) in Saudi Arabia. ${ }^{23}$

Although Brucella spp are not considered to be a common cause of bacterial septic or reactive arthritides, ${ }^{24-27}$ the various types of brucella arthritis may mimic other diseases and thus have to be differentiated from them, especially in brucella endemic areas. For example, brucella polyarthritis may be confused with rheumatic fever ${ }^{14} 2829$ and systemic lupus erythematosus, ${ }^{30}$ brucella monoarthritis with tuberculosis and pyogenic arthritis. ${ }^{15}$ In addition, brucella spondylitis might be misdiagnosed as Pott's disease of the spine, ankylosing spondylitis, and lumbar disc prolapse. ${ }^{15} 25$ Brucella arthritis might be particularly difficult to differentiate from rheumatoid arthritis, especially if the patient serum was positive for rheumatoid factor as was seen in $4 \%$ of our patients. The brucella ELISA, ${ }^{11}$ however, provided a reliable diagnostic test and was not affected by the presence of rheumatoid factor as we showed by the absorption of rheumatoid factor from patient sera positive for this factor. The $4 \%$ seropositivity of rheumatoid factor in patients with brucellosis is similar to that reported in patients with tuberculosis and about the expected prevalence in the general population. $^{31}$ Thus no association of rheumatoid factor with brucella arthritis was found. In brucella endemic areas, however, simultaneous occurrence of brucella arthritis with any one of the above conditions is possible. In these areas a treatment for brucellosis should be considered.

The exact pathophysiology of brucella arthritis is unknown. Gotuzzo et al suggested two pathogenic mechanisms: septic and reactive forms. ${ }^{7}$ The septic form seems more probable as brucella spreads through blood and thus arthritis is probably acquired through the blood stream, as in other bacterial arthritides. ${ }^{26}$ In addition, recovery of brucella from synovial fluid or tissue supports the septic form theory. ${ }^{1232} 33$ The difference between the clinical presentations of the so-called septic and reactive forms of brucellosis might be due to differences in the virulence of brucella micro-organisms in different patients. In addition, the lack of destructive sequelae in the joints of our patients might be due to increased awareness of the condition leading to earlier diagnosis and treatment.

Predisposing conditions in brucella arthritis remain unknown. A genetic predisposition (HLA-B27) was suggested ${ }^{34}$ but could not be confirmed. 1535 The controversial role of bacterial products, exotoxins, endotoxins, or bacterial components such as peptidoglycan and circulating immune complexes in the pathophysiology of bacterial or postinfectious arthritis also remains to be elucidated in brucella arthritis. ${ }^{37}$

Patients with brucella arthritis do not have specific haematological or biochemical findings, as indicated by the complete blood count and liver functions tests. In contrast with other bacterial arthritides, in which leucocytes with polymorphonuclear cells are increased, ${ }^{26}{ }^{27}$ most of our patients had a normal white blood cell count. Yet, leucocytosis occurred in $19 \%$ of our patients with higher values in the subacute group $(25 \%)$. This is in slight contrast with the finding of Andonopoulos et al that absence of peripheral blood leucocytosis was a consistent finding in brucellosis. ${ }^{33}$ In agreement with other reports ${ }^{716}$ the increase of erythrocyte sedimentation rate was moderate in our patients. Around $50 \%$ of our patients showed abnormal increases in one or more liver enzymes, but this cannot be considered specific to brucellosis. The radiographic findings were of minimal diagnostic value as they did not show abnormal (destructive) changes, but they did serve to exclude other diseases.

Synovial fluid analysis was not of particular diagnostic help in this study. On the other hand, Mavridis et al noted that increased mononuclear leucocytes combined with high lactate concentrations in the synovial fluid were helpful in the differential diagnosis of brucella arthritis from rheumatoid and gouty arthritis. ${ }^{32}$ Andonopoulos et al also reported predominance of lymphocytes in the synovial fluid of patients with brucellosis in contrast with the predominance of polymorphs in septic arthritis. ${ }^{33}$ Both series were small, however. In general, the white blood cell count in the synovial fluid in brucella arthritis does not exceed $15 \times 10^{9} / 1$, which is similar to that in reactive arthritis due to Salmonella spp and Yersinia spp but unlike the higher count in other septic arthritides. ${ }^{24} 2627$ Our study showed significant increase in the protein content of the synovial fluid (exudate) while the synovial fluid glucose was normal. In other bacterial arthritides glucose content is usually decreased. ${ }^{26}$ Furthermore, the therapeutic value of aspirating a swollen joint cannot be denied. Our patients felt immediate pain relief after successful aspirations of moderate and severe (but not mild) effusions, especially at the knee joint.

Synovial tissue biopsy ${ }^{12}$ is an invasive and possibly unnecessary procedure in brucellosis. Diagnosis was made in our patients by less invasive procedures. The single biopsy of synovial tissue we carried out did not prove helpful as it showed inflammation of non-specific nature.

Culture provides the definitive diagnosis, but its yield is usually low and variable. ${ }^{7} 16323338$ Gotuzzo et al noted that the type of culture medium used affected recovery of brucella. ${ }^{7}$ Thus, for example, Ruiz-Castaneda's biphasic 
medium showed $50 \%$ recovery of brucella from synovial fluid compared with negative findings when trypticase soy broth medium was used. The latter was used in our study, which might explain the negative brucella culture in the synovial fluid of our patients. Because of the low yield of brucella culture and the long time required for the growth to appear, serological tests have been relied upon in the diagnosis of brucellosis, and ELISA has been found to be particularly helpful, especially in chronic and complicated cases. 91

The prognosis of brucella arthritis remains very good with appropriate and well timed treatment. ${ }^{39}$ Combined treatment with tetracyclines plus streptomycin or gentamicin, rifampicin plus an aminoglycoside, co-trimoxazole plus an aminoglycoside, or oral doxycycline plus rifampicin produced a good response with a low $(<10 \%)$ relapse rate. The last combination is recommended by the World Health Organisation as the once a day regimen had better compliance. ${ }^{4}$

This work was supported by Kuwait University grant No MI052 and Health Research Department grant No BM 474178 MPH, Kuwait (to GFA).

The authors thank $\mathbf{M}$ Haj for her excellent technical assistance and $M$ Siddique for drawing the illustration.

1 Spink $\mathbb{W} \mathbf{W}$. The nature of brucellosis. Minneapolis: University of Minnesota Press, 1956: 145-90.

2 Alausa O K. Brucellosis: socio-economic problems and control in various countries. Trop Geogr Med 1980; 32: 5-11.

3 Matyas Z, Fujikura T. Brucellosis as a wortd problem. Dev Biol Stand 1984; 56: 3-20.

4 Joint FAO/WHO expert committee on brucellosis. 6th report. WHO Tech Rep Ser 1986; No 740.

5 Villiams E Brucellosis. Practitioner 1982: 1507-17.

6 Manes G. Epidemiological situation of brucellosis in the Mediterranean countries. Dev Biol Stond 1984; 56: 739-47.

7 Goturzo E, Alarcón G S, Bocanegra T S, et al. Articular involvement in human brucellosis: a retrospective analysi of 304 cases. Semin Arthritis Rhewem 1982; 12: 245-55.

8 Young E J. Human brucellosis. Rev Infect Dis 1983; 5: $821-42$.

9 Lulu A R, Araj G F, Khateeb M I, Mustafa M Y, Yusuf A R, Fenech F F. Human brucellosis in Kuwait: a prospective study of 400 cases. $Q \mathcal{F}$ Med 1988; 66: 35-54.

10 Alarcon G S, Bocanezra T S, Gotuzzo E, Espinoza L R. The arthritis of brucellosis: a perspective one hundred years after Bruce's discovery. I R hevematol 1987; 14: 1083-5.

11 Araj G F, Lulu A R, Mustafa M Y, Khateeb M I. Evaluation of ELISA in the diagnosis of acute and chronic brucellosis of ELISA in the diagnosis of acute and chronic bruce

12 Kelly P J, Martin W J, Schinger A, Weed L A. Brucellosis of the bones and joints. JAMA 1960; 174: 347-53.
13 Ganado W, Craig A J. Brucellosis myelopathy. I Bome foint Sung [Am] 1958; 40: 1380-8.

14 Norton $W$ L. Brucellosis and rheumatic syndromes in Saudi Arabia. Am Rhewem Dis 1984; 43: 810-5.

15 Al-Rawi Z S, Al-Khateeb N, Khalifa S J. Brucella arthritis among Ireai patients. Br $\mathcal{Y}$ R herwatel 1987; 26: 247.

16 Mousa A M, Muhtaseb S A, Almudallal D S, Khodeir S M, Marafie A A. Osteoarticular complications of brucellosis: a study of 169 cases. Rev Infect Dis 1987; 9: 531-43.

17 Gomez-Reino F J, Mateo I, Fuertes A, Gomez-Reino J J. Brucellar arthritis in children and its successful treatment Brucellar arthritis in children and its successful treatment with trimethoprim-sulphametho

18 Porat S, Shapiro M. Brucella arthritis of the sacro-iliac joint. Infection 1984; 12: 205-7.

19 Bahar R H, Al-Suhaili A R, Mousa A M, Nawaz M K, Kaddah N, Abdul-Dayem H M. Brucellosis: appearance on skeletal imaging. Clin Nucl Med 1988; 13: 102-6.

20 Madkour M M, Sharif H S, Abed M Y, Al-Fayez M A Osteoarticular brucellosis: results of bone scintigraphy in 140 patients. AFR 1988; 150: 1101-5.

21 Lubani M, Sharda D, Helin I. Brucella arthritis in children. Infection 1986; 14: 233-6.

22 Ariza J, Gudiol F, Valverde I, et al. Brucellosis spondylitis: a detailed analysis based on current findings. Rev Infect $D$ is detailed analysis

23 Lifeso R M, Harder E, McCorkell S J. Spinal brucellosis. $\mathcal{J}$ Bone foint Surg [Br] 1985; 67: 345-51.

24 Sommers $H$ M. The microbiology laboratory in the diagnosis of infectious arthritis. Clin Rherm Dis 1978; 4: 63-82.

25 Ebringer R. Spondylarthritis and the post-infectious syn dromes. Rheromatology and Rehabilitation 1979; 18: 218-26.

26 Goldenberg D L, Reed J I. Bacterial arthritis. N Engl f Med 1985; 312: 764-71.

27 Julkunen H. Reactive arthritis. Bull Rheum Dis 1979; 29: 1002-5

28 Al-Rawi Z S, Al-Khateeb N. Clinical features of first attack of rheumatic fever in adults. Rhermatology and Rehabilitation 1982; 21: 195-200.

29 Majeed H A, Yousof A M, Khuffash F A, Yusuf A R Farwana S, Khan N. The natural history of acute rheumatic Farwana S, Khan N. The natural history of acute rheumatic fever in Kuwait: a prospective

30 Al-Rawi Z S, Al-Shaarbaf H, Al-Raheem E, Khalifa S J. Clinical features of early cases of systemic lupus erythematosus in Iraqi patients. Br $\mathcal{F}$ Reumatol 1983; 22: 165-71.

31 Lawrence J S. Relationship of infection to rheumatoid facto in the population. Am Rhewm Dis 1970; 29: 196-7.

32 Mavridis A K, Drosos A A, Tsolas O, Moutsopoulos H M. Lactate levels in brucella arthritis. Rheumatol Int 1984; 4 $169-71$.

33 Andonopoulos A P, Asimakopoulos G, Anastasiou E, Bassaris H P. Brucella arthritis. Scand $\mathcal{F}$ Rheumatol 1986; 15: 377-80.

34 Hodinka L, Gomor B, Meretey K, et al. HLA-B27 associated spondylarthritis in chronic brucellosis. Lancet 1978; i: 499.

35 Alarcon G S, Gotuzzo E, Hinostroza S A, et al. HLA studies in brucellar spondylitis. Clin Rhewmatol 1985; 4: 312-4.

36 Dawes P T Gos K Tissue typing in brucellosis. Ann R hew Dawes P T, Gosh K. T.

37 Bocanegra T S, Gotuzzo E H, Alarcon G S, et al. Circulating immune complexes in acute typhoid fever and brucellosis: correlation with disease activity [Abstract]. Clin Res 1981 29: 381A.

38 Jayakumar R V, Al-Aska A K, Subesinghe N, Wright S G. Unusual presentation of culture positive brucellosis. Postgrad Med F 1988; 64: 118-20.

39 Lubani M M, Dudin K I, Sharda D C, et al. A multicenter therapeutic study of 1100 children with brucellosis. Pediat Infect Dis 1989; 8: 75-8. 